PATIENT PAGE

Section Editors

David C. Spencer, MD

Steven Karceski, MD

\title{
Bone health
}

Steven C. Karceski, MD
In their article "Bone health in young women with epilepsy after one year of antiepileptic drug monotherapy," Dr. Alison Pack and her colleagues ${ }^{1}$ studied how antiseizure medicines affect bones. They followed 93 women for a 1-year period. Because hormones are important for bone health, the authors specifically studied a group of women who had not yet gone through menopause. In addition, Dr. Pack controlled for factors that might have an impact on bone health, such as smoking, drinking alcohol, calcium in the diet, and daily exercise. In short, she tried to eliminate all factors that might affect the bones, so that the only difference between the groups was the kind of seizure medication that they were taking.

The study compared four groups of women. They were taking phenytoin (Dilantin and Phenytek are two trade names), carbamazepine (Tegretol and Carbatrol), lamotrigine (Lamictal), and valproate (Depakote or Depakote ER). To eliminate confusion, the women were limited to taking only one medication for their seizures. Because people sometimes change medications, Dr. Pack only enrolled women who had not changed their medicines in the 6 months before the study started. Similarly, if a woman had changed her medication during the 1-year period, she was removed from the study group.

In each group, bone density was measured using a specific kind of machine (Hologic densitometer). Calcium levels, vitamin D levels, and other markers of bone health were sampled. Each person had these tests both at the beginning and end of the 1-year period. At the end of 1 year, Dr. Pack compared the test results of each group.

The groups were identical in their makeup. The average age of the women was 32 . They all had epilepsy for about 9 years. Each group exercised regularly and took more than $1,000 \mathrm{mg}$ of calcium per day. There were 41 women taking carbamazepine, 23 taking lamotrigine, 15 taking valproate, and 14 taking phenytoin.

WHAT DID THE STUDY SHOW? The first finding was that bone density significantly decreased in the group taking phenytoin. There was a $2.6 \%$ decrease in bone density. When this was compared to women of similar age who were not taking these medicines, the rate of bone loss was only $0.3 \%$. In other words, in a 1-year period, the women taking phenytoin had bone loss 8 times greater than women who were not. In the groups of women taking the other antiseizure medications, there was no change in the bone density results.

The study also showed that the women who were taking phenytoin also had lower vitamin D levels. One reason for this is that phenytoin causes the body to break down vitamin $\mathrm{D}$ more quickly. Vitamin D is an important vitamin for bone health. Therefore, lower levels of vitamin D is one possible explanation for the bone loss in the group of women taking phenytoin.

There were several limitations to the study. In the study, there was no "control" group. In other words, they did not have a group of 93 women, also followed for 1 year, who were not taking antiseizure medications. Instead, they compared their results to information from other studies. In addition, they started out with 147 women, but 54 dropped out during the year. It is possible that if all of the women had completed the study, the results could have been different.

There is still much work to do in this area. This study included only four antiseizure medications. Many more seizure medications are available in the United States, with several in the process of being investigated or approved by the Food and Drug Administration. To what extent these other medications cause bone health problems is unknown. In addition, the way that these other medicines affect bones is still poorly understood. As more is learned about bones and bone health, there may be better ways to prevent or reverse this effect.

\section{REFERENCE}

1. Pack AM, Morrell MJ, Randall A, McMahon DJ, Shane E. Bone health in young women with epilepsy after one year of antiepileptic drug monotherapy. Neurology 2008;70:1586-1593. 
PATIENT PAGE

Section Editors

David C. Spencer, MD

Steven Karceski, MD

\section{About bone health}

WHAT IS IT? Bone health has gained much attention in recent years. Most studies have looked at women who have gone through menopause. In menopause, hormones change dramatically. This change in hormone levels has a direct impact on bone health. After menopause, the bones become weaker. Weakened bones cause postmenopausal women to break their bones more easily.

One solution to this problem is simple: determine other means to make the bones stronger. Taking calcium is one way to do this. Bonestrengthening medications are another. Today, there are many medications that can help to improve bone health. Most people are aware of this fact, because we often see commercials that advertise these medications.

People with epilepsy face the same problem as postmenopausal women. They have a higher rate of broken bones than people who do not have seizures. For a long time, it was not clear why this was happening. For instance, was it because people who had seizures were falling? Did the seizures affect bones? Or was it due to medications?

Before these questions could be answered, scientists needed to understand how bones work. We now know, for instance, that bones are not like rocks. Instead, bones are constantly changing. There are cells called osteoblasts that are always making new bone. Another kind of bone cell, osteoclasts, is continually breaking bone down. It is estimated that our bones "turn over" about once every 3 months as a result of this constant buildup and breakdown.

Many factors influence our bones. Bones need calcium to be strong. If a person does not have enough calcium in his or her diet, he or she may develop weakened bones. However, there is more to the story. In addition to calcium, people need vitamin $\mathrm{D}$ to have strong bones. Vitamin $\mathrm{D}$ (the technical term is 25-hydroxy vitamin D) must be changed by the body to its active form. This is called 1,25 hydroxyvitamin D. Our bodies convert vitamin $\mathrm{D}$ into its active, usable form only in the presence of sunlight. In other words, we need sunlight (just a little) in order to have healthy bones.
Exercise also affects bones. The more a person exercises, the stronger the bones become. This is exactly what happens to muscles as well. Weightlifting strengthens the muscles (and makes them bigger-just ask Governor Arnold Schwarzenegger). Because our muscles are attached to bone, the bones must become stronger as well. If a person is always lifting heavy objects, the osteoblasts (bone forming cells) make more bone. If not, the osteoclasts start working harder to dissolve some of the bone. In short, the human body is very smart, and knows exactly how much muscle and bone it needs.

To some degree, our genes determine bone strength. A strong family history of many broken bones might mean that "weaker" bones run in the family. In addition, things like smoking and drinking alcohol can affect bone health. Finally, certain medicines, like glucocorticoids, a kind of steroid, can weaken bones when taken for long periods of time.

MEASURING BONE STRENGTH Bone strength is easily measured. The most common test is a bone density study, called a "DEXA scan." DEXA stands for dual emission X-ray absorptiometry. In other words, it is as simple as getting an $\mathrm{x}$-ray. Bone density is often measured at the wrist, hip, and lower spine. A score is given for each. If the score is lower than -1.0 , the term "osteopenia" is applied. When the score is less than -2.5 , it is called "osteoporosis." This study used the Hologic densitometer to measure bone density.

\section{BONE HEALTH AND PEOPLE WITH EPILEPSY} People with epilepsy break their bones more often and more easily than people without seizures. Early studies were poorly designed. They did not take into account a person's diet, exercise, sunlight exposure, and other factors that influence bone health. However, recent studies have tried to "control" for all of these factors. In this way, we now understand the problem much better.

Although the final answer is not yet in, people with epilepsy have bone problems because of their medications. This is partly due to the kind of 
medicine that they take. Phenytoin is one of the most commonly used medicines for seizures. Studies have consistently shown that this medicine contributes to bone loss. The longer a person takes this medicine, the more severe the bone loss becomes. In other words, it is not just the medicine, but the length of time that one takes it that causes a problem.
Studies like this one show that bone loss can occur after taking a medicine for 1 year. It takes longer to get to the point where the bones will break more easily. In recognizing the problem, doctors can take steps to prevent it. One answer is to stop smoking, take calcium, and exercise regularly. For some people with seizures, a change to another medication may be needed. 


\title{
Neurology
}

\author{
Bone health \\ Steven C. Karceski \\ Neurology 2008;70;e71-e73 \\ DOI 10.1212/01.wnl.0000313935.44801.3b
}

This information is current as of April 28, 2008

Updated Information \&

Services

References

Permissions \& Licensing

Reprints including high resolution figures, can be found at: http://n.neurology.org/content/70/18/e71.full

This article cites 1 articles, 1 of which you can access for free at: http://n.neurology.org/content/70/18/e71.full\#ref-list-1

Information about reproducing this article in parts (figures,tables) or in its entirety can be found online at:

http://www.neurology.org/about/about_the_journal\#permissions

Information about ordering reprints can be found online:

http://n.neurology.org/subscribers/advertise

Neurology $®$ is the official journal of the American Academy of Neurology. Published continuously since 1951, it is now a weekly with 48 issues per year. Copyright . All rights reserved. Print ISSN: 0028-3878. Online ISSN: $1526-632 \mathrm{X}$

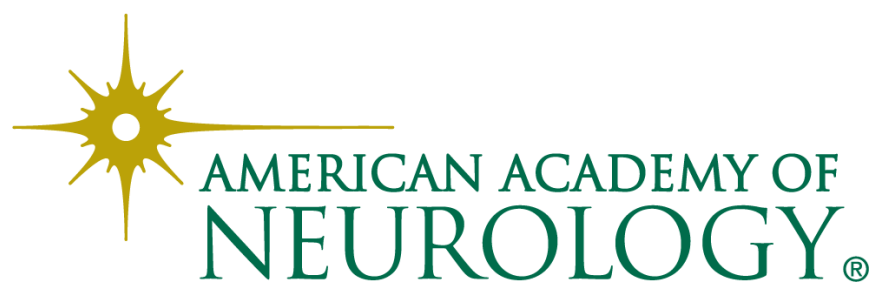

